\title{
Article
}

Mycosphere

\section{Mycosphere Essay 16: Colletotrichum: Biological control, bio- catalyst, secondary metabolites and toxins}

\author{
Jayawardena $\mathrm{RS}^{1,2}$, Li XH ${ }^{1}$, Liu $\mathrm{M}^{1}$, Zhang $\mathrm{W}^{1}$ and Yan JY ${ }^{1 *}$ \\ ${ }^{1}$ Institute of Plant and Environment Protection, Beijing Academy of Agriculture and Forestry Sciences, Beijing \\ 100097, People's Republic of China \\ ${ }^{2}$ Center of Excellence in Fungal Research and School of Science, Mae Fah Luang University, Chiang Rai \\ 57100, Thailand
}

Jayawardena RS, Li XH, Liu M, Zhang W, Yan JY 2016 - Mycosphere Essay 16: Colletotrichum: Biological control, bio-catalyst, secondary metabolites and toxins. Mycosphere 7(8) 1164-1176, Doi 10.5943/mycosphere/si/2c/7

\begin{abstract}
The genus Colletotrichum has received considerable attention in the past decade because of its role as an important plant pathogen. The importance of Colletotrichum with regard to industrial application has however, received little attention from scientists over many years. The aim of the present paper is to explore the importance of Colletotrichum species as bio-control agents and as a bio-catalyst as well as secondary metabolites and toxin producers. Often the names assigned to the above four industrial applications have lacked an accurate taxonomic basis and this needs consideration. The current paper provides detailed background of the above topics.
\end{abstract}

Key words - biotransformation - colletotrichin - mycoherbicide - mycoparasites pathogenisis - phytopathogen

\section{Introduction}

Colletotrichum was introduced by Corda (1831), and is a coelomycete belonging to the family Glomerellaceae (Maharachchikumbura et al. 2015, 2016). Species of this genus are widely known as pathogens of economical crops worldwide (Cannon et al. 2012). However, these species also occur as endophytes and saprobes in nature (Manamgoda et al. 2013, Jayawardena et al. 2016). In the past decade this genus has received a tremendous amount of attention due to its complexity in phylogeny, as well as host pathogen interactions (Damm et al. 2012a, b, 2013, 2014, Hyde et al. 2014, Liu et al. 2015). However, the importance of this genus in industrial applications has been overlooked over many years. Species of Colletotrichum have been identified as significant bio-control agents (Askew et al. 2011). They can also be utilized in biotechnological applications (García-Pajón \& Collado 2003). The aim of the present paper on Colletotrichum is to review its importance as biological control agents, bio-catalysts, and its secondary metabolite and toxin production. 


\section{Colletotrichum as a bio-control agent}

Some of the species of Colletotrichum have shown great potentials as bio-control agents. Most of the Colletotrichum species are hemibiotrophic (Cannon et al. 2012). They have an initial biotrophic phase followed by a virulent necrotrophic phase leading to quick death of the host. This makes them qualified as biological control agents, especially if they are highly host-specific (Goodwin 2001). The natural spread and persistence of inoculums in species is also restricted, making them more suitable as bio-control agents.

\section{Mycoherbicides}

Mycoherbicides are fungal pathogens that are applied for the sole purpose to control a population of weeds (Templeton 1991).

Templeton (1991) mentioned during that time there were five strains of Colletotrichum species which had a good prospect for developing into myco-herbicides. The author also mentioned that according to a literature survey, 19 strains of Colletotrichum have been considered as possible myco-herbicides. Two myco-herbicides known as Collego and Lubao have been used more than nine years (Templeton 1991). Collego is used to control Northern Jointvetch (Aeschynomene virginica) which is a native, annual weed in rice and soybean fields in Arkansas, USA (Bowers 1986). A water soluble dried conidial preparation of Colletotrichum aeschynomenes is used in this myco-herbicide (Templeton 1991). A strain identified as Colletotrichum gloeosporioides "f. sp. cuscutae" was developed as a mycoherbicide "Lu Bao 1" against Cuscuta australis and Cuscuta chinensis (Dodder) in China (Zhang 1985). This strain was included in the study of Guerber et al. (2003) and was identified to belong to the acutatum species complex. However, its current species status is unclear (Damm et al. 2012b).

Colletotrichum gloeosporioides had been suggested as a possible bio-control agent for Clidemia hirta which is an introduced weed in Hawaiian forests (Trujillo et al. 1986). Isolates of $C$. clidemiae (earlier referred to as $C$. gloeosporioides "f. sp. clidemiae") were highly pathogenic to Clidemia, but not to the other species of Melastomataceae (Trujillo et al. 1986, Weir et al. 2012). Colletotrichum gloeosporioides f. sp. salsolae (which is now known as $C$. salsolae) was evaluated as a bio-control agent for Russian thistle or tumbleweed which is an introduced invasive weed in North America (Berner et al. 2009). Most introduced and weedy species of the genus Salsola were very susceptible and damaged by $C$. salsolae. Killgore et al. (1999) reported that the isolates recognized as C. gloeosporioides "f. sp. miconiae" were highly specific pathogens of Miconia clavescens, but this species was unable to infect Clidemia hirta which is a close relative. However, the species name of this pathogen is unresolved (Weir et al. 2012).

Boyette et al. (2007) discussed $C$. truncatum is a potential mycoherbicide for Sesbania herbacea, which is an introduced plant species in Canada. Daigle \& Cotty (1994) also elaborated that this species can be used as a mycoherbicide against Sesbania herbacea. Cartwright \& Templeton (1989) did a preliminary assessment of $C$. truncatum (syn. $C$. capsici) as a potential mycoherbicide for the control of Ipomoea lacunosa which is a weed in cotton, peanut and soybean fields. The results showed that all the seedlings of I. lacunosa were killed within 5-7 days after inoculation, supporting the potential of $C$. truncatum as a commercial mycoherbicide.

Colletotrichum coccodes has been examined as a selective bio-control agent for Abutilon theophrasti (Velvet leaf) which is an annual weed in the corn and soybean fields of eastern Mediterranean countries, Canada and the USA (Wymore et al. 1988). Mass production of spores is an essential step when commercializing a prospective mycoherbicide. Xu et al. (1997) introduced a modified Richards' solution as a low-cost and effective medium for spore production in this species. 
Colletotrichum graminicola strain KA001 was identified as a potential mycoherbicide to control Echinochloa sp., which is a destructive weed in rice fields (Yang et al. 2000). Colletotrichum graminicola isolated from Sorghum halepense (Johnson grass), an introduced perennial grass, was also evaluated as a potential mycoherbicide against this host (Chiang et al. 1989).

An isolate of $C$. gloeosporioides f. sp. malvae, which is now identified as $C$. tebeestii belonging to the orbiculare species complex (Bailey et al. 1996, Damm et al. 2013) has been developed as a mycoherbicide against the annual weeds Malva pusilla (Round-leaved mallow) and Abutilon theophrasti (Velvetleaf) in strawberry fields in Canada and the USA. It has been registered under the name BioMal by Philom Bios, Canada (Templeton 1992). However, Damm et al. (2013) mentioned that this product is not commercially available at present.

A strain of Colletotrichum orbiculare (today identified to be C. spinosum) has been developed as an herbicide against anthracnose of Xanthium spinosum (Spiny cockleburr) which is a weed in sheep grazing areas and irrigated crops in Australia (Auld et al. 1988, 1990, Templeton 1991, Auld \& Say 1999). Colletotrichum malvarum which belongs in the orbiculare species complex has been tested as a mycoherbicide for bio-control of prickly sida (Sida spinosa) (Templeton 1974, Kirkpatrick et al. 1982). Strains tested by Kirkpatrick et al. (1982) were pathogenic to hollyhock (Althaea rosea) and prickly sida qualifying this species as a bio-control agent.

Colletotrichum linicola (today known as $C$. lini) belonging to the destructivum species complex strain from field bindweed (Convolvulus arvensis) in Turkey (Tunali et al. 2008), was tested to be effective as a potential bio-control agent against the host plant (Tunali et al. 2009). However, the identification was solely based on the ITS sequence, thus the identity of this strain needs to be confirmed with analyses of additional loci (Damm et al. 2014).

\section{Mycofungicides}

Several studies have shown that endophytic Colletotrichum strains (belonging to the gloeosporioides species complex) provide protection to Theobroma cacao against Phytophthora pathogens, by inducing the plants' intrinsic defence pathways (Arnold et al. 2003, Mejía et al. 2008, Rojas et al. 2010). However, the strains were not identified to the species level.

\section{Mycoparasites}

Association of Colletotrichum species with insects as entomopathogens might be considered surprising. A series of strains were isolated from an epizootic infection of the exotic scale insect Fiorinia externa in the New England region. The species was named as $C$. acutatum var. fioriniae (today known as C. fioriniae) (Marcelino et al. 2008, Damm et al. 2012 b). This insect is a sap-sucker and $C$. fioriniae was found to occur widely as an endophyte both in the host plant of the scale insect, Tsuga canadensis and in a phylogenetically diverse set of associated plants (Marcelino et al. 2009). This species can be used to control populations of $F$. externa.

Two Colletotrichum strains (ARSEF4360 and EMA26) isolated from the economically important citrus scale insect, Orthezia praelonga in Brazil (Cesnik et al. 1996), have shown entomopathogenic activity against this insect (Marcelino et al. 2008). These two strains were initially reported as C. gloeosporioides "f. sp. ortheziidae", but Marcelino et al. (2008) showed that this species belongs to the acutatum species complex. Damm et al. (2012b) mentioned that these two strains have only 2 bp differences with $C$. nymphaeae and probably belong to $C$. nymphaeae. However, these strains are apparently being used 
effectively as a biological control agent against Orthezia praelonga in Brazil (Cesnik et al. 1996, Cesnik \& Ferraz 2000).

In order to identify other Colletotrichum species that can be used as bio-control agents, further studies are needed.

\section{Colletotrichum as a bio-catalyst}

Microorganisms have potential application in biotransformation processes for the organic synthesis of small molecules, which nourish the chemical, pharmaceutics and agricultural industries. Bio-catalytic process may offer cheaper alternatives and several examples of Colletotrichum as a bio-catalyst are given in this section.

Colletotrichum gloeosporioides (syn Glomerella cingulata) has been used in the biotransformation of saturated and unsaturated acyclic terpenoids. The saturated, acyclic monoterpenes tetrahydogeraniol and tetrahydrolavandulol were oxidized selectively at the isopropyl group. With the use of $C$. gloeosporioides as a bio-catalyst on racemic monoterpene lavandulol, 100\% pure enantioselective cyclization was obtained (García-Pajón et al. 2003). Bio-tranformation of racemic 4-methylcyclohexanone and 4-ethylcyclohexanone can be carried out with the use of $C$. dematium, $C$. fragarie (today known as $C$. theobromicola), C. gloeosporioides, C. graminicola, C. lindemuthianum, C. orbiculare and C. trifoli (Miyazawa et al. 2000). Colletotrichum gloeosporioides and C. musae have been examined for their potential in the biotransformation of steroids (Wilson et al. 1999). The authors noted that the products isolated were those of oxidation and reduction. However, $\alpha, \beta-$ unsaturated carbonyl functionalities were left untouched and minute quantities of hydroxylated steroids were formed during this bio-trnasformation (García-Pajón et al. 2003).

The microbial transformation of 2-phenilethanol and acetophenone was investigated using $C$. acutatum, which showed a strong tendency to produce hydroxylations on the substituents' attached to the aromatic ring (Aristizabal et al. 2008). Additionally, this species was able to reduce the carbonyl group effectively and produce esterification reactions in the hydroxyl groups from primary alcohols. Velasco et al. (2010) demonstrated that C. acutatum can be used to transform cinnamyl alcohol into 2-phenulethanol, a colourless liquid possessing a faint but lasting rose petal odor. Transformation of propenylbenzenes using microbes can provide a cleaner and cheaper alternative in natural production of flavours and fragrances. In order to confirm this, Velasco-Bucheli et al. (2015) proposed a pathway of the bio-transformation of trans-anethole using C. acutatum.

A strain of $C$. lini (ST-1) has been shown to selectively hydroxylate steroid substances (with exception of estradiol, estrone and progesterone) with 70-85\% conversion rate and 60$76 \%$ total product yield (Wu et al. 2015).

\section{Secondary metabolites (SM) of Colletotrichum}

Fungi produce an enormous array of secondary metabolites, which may serve as signalling molecules and toxins against microorganisms (antimicrobials), plants (phytotoxins) or animals and humans (mycotoxins). Endophytic fungi are capable of producing a multitude of low-molecular-mass compounds known as secondary metabolites, which have roles in a range of cellular processes such as transcription, development and intercellular communication (Brakhage 2013). In addition, many of these compounds have important applications in pathogen control and in medicine. Species of Colletotrichum have been identified to produce secondary metabolites and a brief review of them is given in this section.

\section{Secondary metabolites towards pathogenesis}


Colletotrichum species are fungal pathogens that devastate crop plants worldwide and their host infection involves specialized cell types that are associated with penetration, biotrophy and necrotrophy (O'Connell et al. 2012). Colletotrichum species have been identified to produce a variety of SM genes, including flavones, peptides and terpenes (Crouch et al. 2014). They have also been identified to produce polyketide derived 1,8dihydroxynapthene (DHN) melanin, which is essential in appressorium mediated host penetration (Kubo \& Furusawa 1991, Singh et al. 2010).

Asakura et al. (2012) and Lin et al. (2012) showed that the primary and secondary metabolism regulates lipolysis and melanization in appressoria as well as conidial pigmentation of Colletotrichum orbiculare. Genome study of Crouch et al. (2014) has revealed that Colletotrichum species have large and complex storage of enzymes for lignocellulose degradation. O'Connell et al. (2012) compared genome and transcriptome sequence of $C$. higginsianum (belonging to the destructivum species complex) with those of $C$. graminicola (belonging to the graminicola species complex). This study revealed that both species possessed an unusually large set of pathogenicity-related genes, combining features of both biotrophic and necrotrophic pathogens. Similar to necrotrophs, genes encoding plant cell wall degrading enzymes, proteases and secondary metabolism enzymes in the tested species were expanded. However, these two species also encode large numbers of effector proteins for host manipulation, more similar to biotrophs. Transcriptome analyses by O'Connell et al. (2012) showed that most effectors and SM genes are stage-specific and expressed early during appressorium penetration and biotrophy. O' Connell et al. (2012) identified 42 SM gene clusters in C. graminicola and 39 in C. higginsianum. Each SM gene cluster is probably involved in the biosynthesis of specific metabolite (Collemare et al. 2008). Therefore, each Colletotrichum species studied in O'Connell et al. (2012) can be expected to produce unusually, large and diverse spectrum of SM.

Limitation of nitrogen has been shown to be an essential stimulus for the production of SMs (Pusztahelyi et al. 2015). Kroll et al. (2014) showed the significance of global nitrogen regulators for the development of pathogenicity for $C$. acutatum and $C$. lindemuthianum. Hiruma et al. (2016) showed that tryptophan (Trp)-derived secondary metabolites are required for beneficial interactions between Arabidopsis thailandica and its endophytic $C$. tofieldiae. Weber et al. (2013) studied the influence of $C$. simmondsii infection on selected primary and secondary metabolites in strawberry runners and fruits. In this study, 12 forms of ellagic acid, nine flavanols and eight flavonols were identified from strawberry runners, while in fruits nine forms of ellagic acid, six flavonols, seven flavonols and four anthocyanins were identified.

Baroncelli et al. (2016) studied the genomes of $C$. fioriniae, C. fructicola, $C$. gloeosporioides, C. graminicola, C. higginsianum, C. nymphaeae, C. orbiculare, C. salicis, $C$. simmondsii and $C$. sublineola. According to their study, the more common hybrid gene cluster t1PKS-terpene (meroterpenoids) was found in seven out of ten genomes. These terpenoid clusters are potential candidates for synthesizing antimicrobial triterpenoids (ergosterol and its derivatives) by different species of Colletotrichum (Lu et al. 2000).

Colletotrichum orbiculare possess a number of secondary metabolites including 24 polyketide synthases (PKS), 1 PKS-like, 11 nonribosomal peptide synthases (NRPS), 9 NPRS-like, 3 PKS-NPRS hybrid backbone synthases and 11 demethylallyl tryptophan synthases (DMAT) (Gan et al. 2013). However, C. gloeosporioides appears to have a greater capacity for secondary metabolite production than $C$. orbiculare. This species produces 34 PKS, 10 PKS-like, 14 NRPS, 10 NRPS-like, 6 PKS-NRPS hybrids and 8 DMAT (Gan et al. 2013).

A tetrahydroxylated compound with antioxidant properties was isolated from $C$. gloeosporioides (Femeníaríos et al. 2007). Mycosporine-alanine, a spore germination 
inhibitor has been recorded from C. graminicola (Leite \& Nicholson 1992). The study of Somashekhara Achar \& Shivanna (2013) indicated that certain secondary metabolites like alkaloids, flavonoids, phenols and sterols in Clitorea ternate plants were significantly influenced due to disease caused by $C$. dematium.

\section{Secondary metabolites against pathogens}

A potential opportunity to control crop pathogens is the use of endophytes and their derived secondary metabolites.

Ester compounds namely Monorden and monicillins I, II and III have been isolated from $C$. graminicola (Wicklow et al. 2009). These compounds have shown antifungal activities against the foliar pathogens Alternaria alternata, Bipolaris zeicola, and Curvularia lunata. A new macrolide compound named colletotriolide was isolated from an endophyte Colletotrichum sp. isolated from Pandanum amaryllifolius in the Philipines (Bungihan et al. 2013). Biological evaluation of this macrolide showed that it has a low activity against Escherichia coli.

Colletotric acid, a tridepside, was identified from the liquid culture of an endophytic C. gloeosporioides which colonizes the stems of Artemisia mongolica, an asian plant that shows resistance to insect and pathogens (Mousa \& Raizada 2013). Zou et al. (2000) showed that this compound has anti-microbial activity against Bacillus subtilis, Micrococcus luteus, Staphylococcus aureus and the fungus Helminthosporium sativum.

Colletotrichum has been successfully used in the biotransformation of steroids giving more highly oxidized metabolites (Wilson et al. 1999). Lu et al. (2000) isolated five steroids from an endophytic Colletotrichum sp. inhabiting the stems of Artemisia annua, a Chinese medicinal herb. Those steroids proved to have antifungal activities against several crop pathogens Gaeumannomyces graminis, Helminthosporium sativum, Phytophthora capisici and Rhizoctonia cerealis. These steroids also showed antibacterial activity against Aspergillus niger, Bacillus subtilis, Micrococcus luteus (a human skin pathogen), Pseudomonas sp., Sarcina lutea, and Staphylococcus aureus (Lu et al. 2000, Mousa \& Raizada 2013).

\section{Secondary metabolites as medicine}

Taxol is a powerful and complex anti-cancer compound that was first isolated from the bark of Taxus brevifolia. Senthikumar et al. (2013) screened an endophytic strain of $C$. gloeosporioides which was isolated from leaves of Tectonia grandis, for the production of taxol. This study proved that the strain screened was able to produce taxol that was identical to the authentic taxol. A strain of $C$. gloeosporioides (TA67) has showed capable of producing taxol (163.4 $\mu \mathrm{g} / \mathrm{l})$ (Xiong et al. 2013).

Ren et al. (2008) showed that $C$. dematum isolated from Pteromischum sp. growing in tropical forest of Costa Rica produced an antimycotic peptide collutelin A. It exhibited strong immunosuppressive activity by inhibiting CD4 (+) Tcell activation of Interleukin 2 production.

Betutilinic acid and betulonic acid are triterpenoids that have anti-cancer, anti-HIV and anti-malaria properties (Yogeeswari \& Sriram 2005). In the study carried out by Bastos et al. (2007), Colletotrichum strain DPB136, isolated from corn leaves were identified to be useful for mild, selective oxidations of lupine substrates at positions C-3, C-7, C-15, C-25 and C-30.

Huperzine A is a pyridine-type alkaloid which was initially isolated from Huperzia serrata. It is an effective and safe treatment of Alzheimer's disease. A C. gloeosporioides strain ES026 was identified to produce huperzine A (Zhang et al. 2015). 


\section{Toxins produced by Colletotrichum}

Phytotoxins are natural compounds which have a deleterious effect on plants (Kenfield et al. 1989). Secondary metabolite production by $C$. tabacum (earlier known as $C$. nicotianae - ATCC 11995) was extensively studied during the 1970s, leading to the identification and structural characterisation of two novel terpenoid phytotoxins, colletotrichin and colletopyrone (Gohbara et al. 1976, 1978). Colletotrichin is one of three non-host-specific, norditerpene- $\gamma$-pyrone phytotoxins produced by Colletotrichum sp. (Gohbara et al. 1977, 1978). In earlier literature this phytotoxin was referred to as acetylcolletotrichin (Grove et al. 1966). The two other phytotoxins in this group are colletotrichin B and colletotrichin C. These phytotoxins were able to produce symptoms resembling tobacco anthracnose when tested on tobacco leaves (García-Pajón \& Collado 2003).

Foucher et al. (1974) found that colletotrichin can inhibit respiratory electron transport in isolated rat liver and rat and pig kidney mitochondria. As this study provides evidence for colletotrichin being toxic to mammals, it creates an interesting research field to study. Duke et al. (1992) determined the rapid loss of membrane integrity in leaves of tobacco, cucumber and four Solanum species, due to the effect of colletotrichin. The data in this study indicated that colletotrichin caused oxidative plasmalemma destruction by an unknown mechanism. Sidereophore ferricrocin is another toxin, isolated from a strain of $C$. gloeosporioides which has phytotoxic activity in grass cotyledons (Ohra et al. 1995).

Colletotrichum dematium strain FGCC\#20 has been identified to produce phytotoxin against Parthenium hyspterophorus (Singh et al. 2010).

\section{Future perspectives}

Use of molecular data together with morphology has allowed us to identify the species of Colletotrichum more precisely (Hyde et al. 2014). However, there is still a need to clarify names that can be used in biotechnology. Then biotechnology can confidently apply names to the fungi that are important in bio-prospecting and bio-control strategies can be implemented with confidence in agriculture.

\section{Acknowledgment}

We are grateful to the CARS-30, JNKYT201605, Youth Foundation of Beijing Academy of Agriculture and Forestry Sciences (number QNJJ 201515) and Mushroom Research Foundation, Chiang Rai, Thailand. The authors have no conflict of interest to declare.

\section{References}

Aristizábal DA, Lezcano CS, García CM, Durango DL. 2008 - Biotransformación de los sustratos 2 feniletanol y acetofenona con el hongo fitopatógeno Colletotrichum acutatum. Revista Colombiana Química. 37, 7-19.

Arnold AE, Mejía LC, Kyllo D, Rojas EI, Maynard Z, Robbins N, Herre EA. 2003 Fungal endophytes limit pathogen damage in a tropical tree. Proceedings of the National Academy of Science, USA 100, 15649-15654.

Asakura M, Yoshino K, Hill AM, Kubo Y, Sakai Y, Takano Y. 2012 - Primary and secondary metabolism regulates lipolysis in appressoria of Colletotrichum orbiculare. Fungal Genetics and Biology 49, 967-975.

Askew SE, Shamoun SF, van der Kamp BJ. 2011 - Assessment of Colletotrichum gloeosporioides as a biological control agent for management of hemlock dwarf mistletoe (Arceuthobium tsugense). Forest Pathology 41, 444-452. 
Auld BA, Say MM. 1999 - Comparison of isolates of Colletotrichum orbiculare from Argentina and Australia as potential bioherbicides for Xanthium spinosum in Australia. Agriculture, Ecosystems and Environment 72, 53-58.

Auld BA, McRae CF, Say MM. 1988 - Possible control of Xanthium spinosum by a fungus. Agriculture, Ecosystems and Environment 21, 219-223.

Auld BA, Say MM, Ridings HI, Andrews J. 1990 - Field application of Colletotrichum orbiculare to control Xanthium spinosum. Agriculture, Ecosystems and Environment 32, 315-323.

Bailey JA, Nash C, Morgan LW, O'Connell RJ, TeBeest DO. 1996 - Molecular taxonomy of Colletotrichum species causing anthracnose on the Malvaceae. Phytopathology 86, 1076-1083.

Baroncelli R, Amby DB, Zapparata A, Sarrocco S, Vannacci G, Le Floch G, Harrison RJ, Holub E, Sukno SA, Sreenivasaprasad S, Thon MR. 2016 - Gene family expansions and contractions are associated with host range in plant pathogens of the genus Colletotrichum. BMC genomics 17, article 555.

Bastos DZL, Pimentel IC, de Jesus DA, de Oliveira BH. 2007 - Biotransformation of betulinic and betulonic acids by fungi. Phytochemistry 68, 834-839.

Berner DK, Bruckart WL, Cavin CA, Michael JL, Carter ML, Luster DG. 2009 - Best linear unbiased prediction of host-range of the facultative parasite Colletotrichum gloeosporioides f. sp. salsolae, a potential biological control agent of Russian thistle. Biological Control 51, 158-168.

Boyette CD, Jackson MA, Bryson CT, Hoagland RE, Connick WJ, Jr. Daigle DJ. 2007 Sesbania exaltata biocontrol with Colletotrichum truncatum micro-sclerotia formulated in 'Pesta' granules. Biocontrol 52, 413-426.

Bowers RC. 1986 - Commerlization of Collego ${ }^{\text {TM }}$ - an industrialist's view. Weed Science 34, (Supp.1) 24-25.

Brakhage AA. - Regulation of fungal secondary metabolism. Nature Reviews Microbiology $11,21-32$.

Bungihas MF, Tan MA, Takayama H, dela Cruz TEE, Nonato MG. 2013 - A new macrolide isolated from the endophytic fungus Colletotrichum sp. Philippine Science Letters 6, $57-73$.

Cannon PF, Damm U, Johnston PR, Weir BS. 2012 - Colletotrichum current status and future directions. Studies in Mycology 73, 181-213.

Cartwright DK, Templeton GE. 1989 - Preliminary evaluation of a dodder anthracnose fungus from China as a mycoherbicide for dodder control in the USA. Proceedings of the Arkansas Academy of Science 43, 15-18.

Cesnik R, Ferraz JNG. 2000 - Orthezia praelonga, (Hemiptera, Ortheziidae) biologia, controle químico e biológico. Jaguariúna: embrapa meio ambiente. Boletim Pesquisa $9,27$.

Cesnik R, Ferraz JNG, Oliveira RCAL, Arellano F, Maia AH. 1996 - Controle de Orthezia praelonga com o fungo Colletotrichum gloeosporioides isolado Orthezia, na regiao de Limeira, SP. Proceedings, 5 Simpósio de Controle Biológico, Foz de Iguaçu, Brazil.

Chiang MY, Van Dyke CG, Leonard KJ. 1989 - Evaluation of endemic foliar fungi for potential biological control of Johnson grass (Sorghum halepense): Screening and host range tests. Plant Disease 73, 459-464.

Collemare J, Billard A, Bohnert HU, Lebrun MH. 2008 - Biosynthesis of secondary metabolites in the rice blast fungus Magnaporthe grisea: the role of hybrid PKSNRPS in pathogenicity. Mycological Research 112, 207-215. 
Corda ACI. 1831 - Die Pilze Deutschlands. In: Sturm J (ed) Deutschlands Flora in Abbildungen nach der Natur mit Beschreibungen. Sturm, Nürnberg vol. 3, Abt. 12, 33-64, tab, 21-32.

Crouch J, O’Connell R, Gan P, Buiate E, Torres MF, Beirn L, Shirasu K, Vaillancourt L. 2014 - The genomics of Colletotrichum. In: Dean RA, Lichens-Park A, Kole Chittaranjan (eds. Genomics of Plant-Associated Fungi: Monocot Pathogens. Springer, Berlin, Heidelberg 69-102.

Daigle DJ, Cotty PJ. 1994 - Stability of Colletotrichum truncatum in culture influences mycoherbicide efficacy. Mycologia 86, 397-400.

Damm U, Cannon PF, Woudenberg JHC, Johnston PR, Weir BS, Tan YP, Shivas RG, Crous PW. 2012a - The Colletotrichum boninense species complex. Studies in Mycology $73,1-36$.

Damm U, Cannon PF, Woudenberg JHC, Crous PW. 2012b - The Colletotrichum acutatum species complex. Studies in Mycology 73, 37-113.

Damm U, Cannon PF, Liu F, Barreto RW, Guatimosim E, Crous PW. 2013 - The Colletotrichum orbiculare species complex: important pathogens of field and weeds. Fungal Diversity 61, 29-59.

Damm U, O'Connell RJ, Groenewald JZ, Crous PW. 2014 - The Colletotrichum destructivum species complex - hemibiotrophic pathogens of forage and field crops. Studies in Mycology 79, 49-84.

Duke SO, Gohbara M, Paul RN, Duke MV. 1992 - Colletotrichin causes rapid membrane damage to plant cells. Journal of phytopathology 134, 289-305.

Femeníaríos M, Garcíapajón CM, Hernándezgalán R, Macíassánchez AJ, Collado IG. 2007 Synthesis and free radical scavenging activity of a novel metabolite from the fungus Colletotrichum gloeosporioides. ChemInform 16, 5836-5839.

Foucher B, Chappell JB, McGivan JD. 1974 - The effects of acetylcolletotrichin on the mitochondrial respiratory chain. Biochemical Journal 138, 415-423.

Gan P, Ikeda K, Irieda H, Narusaka M, O'Connell RJ, Narusaka Y, Takano Y, Kubo Y, Shirasu K. 2013 - Comparative genomic and transcriptomic analyses reveal the hemibiotrophic stage shift of Colletotrichum fungi. New Phytologist 197, 12361249.

García-Pajón CM, Collado IG. 2003 - Secondary metabolites isolated from Colletotrichum species. Natural Product Reports 20, 426-431.

Gohbara M, Hyeon S-B, Suzuki A, Tamura S. 1976 - Isolation and structure elucidation of colletopyrone from Colletotrichum nicotianae. Agricultural and Biological Chemistry 40, 1453-1455.

Gohbara M, Kosuge Y, Suzuki A, Tamura S, Ohashi Y, Sasada Y. 1977 - Colletotrichin monohydrate methanol solvate. Acta Crystallographica Section B: Structural Crystallography and Crystal Chemistry 33, 1276-1278.

Gohbara M, Kosuge Y, Yamasaki S, Kimura Y, Suzuki A, Tamura S. 1978 - Isolation, structures and biological activities of Colletotrichins, phytotoxic substances from Colletotrichum nicotianae. Agricultural Biology and Chemistry 42, 1037-43.

Goodwin PH. 2001 - A molecular weed-mycoherbicide interaction: Colletotrichum gloeosporioides f. sp. malvae and round-leaved mallow, Malva pusilla. Canadian Journal of Plant Pathology 23, 28-35.

Grove JF, Speake RN, Ward G. 1966 - Metabolic products of Colletotrichum capsici: isolation and characterisation of acetylcolletotrichin and colletodiol. Journal of the chemical society C: Organic 230-234. 
Guerber JC, Liu B, Correll JC, Johnston PR. 2003 - Characterization of diversity in Colletotrichum actutatum sensu lato by sequence analysis of two gene introns, mtDNA and intron RFLPs, and mating compatibility. Mycologia 95, 872-895.

Hiruma K, Gerlach N, Sacristán S, Nakano RT, Hacquard S, Kracher B, Neumann U, Ramírez D, Bucher M, O’Connell RJ, Schulze-Lefert P. 2016 - Root endophyte Colletotrichum tofieldiae confers plant fitness benefits that are phosphate status dependent. Cell 165, 464-474.

Hyde KD, Nilsson RH, Alias SA, Ariyawansa HA, Blair JE, Cai L, de Cock AWAM, Dissanayake AJ, Glockling SL, Goonasekara ID, Gorczak M, Hahn M, Jayawardena RS, van Kan JAL, Laurence MH, Lévesque CA, Li XH, Liu JK, Maharachchikumbura SSN, Manamgoda DS, Martin FN, McKenzie EHC, McTaggart AR, Mortimer PE, Nair PVR, Pawłowska J, Rintoul TL, Shivas RG, Spies CFJ, Summerell BA, Taylor PWJ, Terhem RB, Udayanga D, Vaghefi N,Walther G,Wilk M,WrzosekM, Xu JC, Yan JY, Zhou N. 2014 - One stop shop: backbones trees for important pytopathogenic genera: I. Fungal Diversity 67, 21125.

Kroll K, Pähtz V, Kniemeyer O. 2014 - Elucidating the fungal stress response by proteomics. Journal of Proteomics 97, 151-163.

Jayawardena RS, Hyde KD, Damm U, Cai L, Liu M, Li XH, Zhang W, Zhao WS, Yan JY. 2016 - Notes on currently accepted species of Colletotrichum. Mycosphere (This issue).

Kenfield D, Hallock Y, Clardy J, Strobel G. 1989 - Curvulin and $O$-Methylcurvulinic acid: Phytotoxic meatbolites of Drechslera indica which cause necroses on purslane and spiny amaranth. Plant Science 60, 123-127.

Killgore EM, Sugiyama LS, Barreto RW, Gardner DE. 1999 - Evaluation of Colletotrichum gloeosporioides for Biological Control of Miconia calvescens in Hawaii. Plant Disease 83, 964.

Kirkpatrick TL, Templeton GE, TeBeest DO. 1982 - Potential of Colletotrichum malvarum for biological control of prickly sida. Plant Disease 66, 323-325.

Templeton GE. 1991 - Use of Colletotrichum strains as mycoherbicides. In: Colletotrichum: Biology, pathology and control (Bailey JA and Jeger MJ Eds.). CAB International, Wallingford, UK 358-380.

Kubo Y, Furusawa I. 1991 - Melanin biosynthesis. Prerequisite for successful invasion of the host by appressoria of Colletotrichum and Pyricularia. In: The Fungal Spore and Disease Initiation in Plants and Animals (Cole GT and Hoch HC Eds.). Plenum, New York 205-18.

Leite B, Nicholsin RL. 1992 - Mycosporine-alanine: a self-inhibitor of germination from the conidial mucilage of Colletotrichum graminicola. Experimental Mycology 16, 7686.

Lin SY, Okuda A, Ikeda K, Okuno T, Takano Y. 2012 - LAC2 Encoding a secreted laccase is involved in appressorial melanization and conidial pigmentation in Colletotrichum orbiculare. Molecular Plant-Microbe Interactions 25, 1552-1561.

Liu F, Weir BS, Damm U, Crous PW, Wang Y, Liu B, Wang M, Zhang M, Cai L. 2015 Unravelling Colletotrichum species associated with Camellia: employing ApMat and GS loci to resolve species in the C. gloeosporioides complex. Persoonia 35, 63-86.

Lu H, Zou WX, Meng JC, Hu J, Tan RX. - 2000 New bioactive metabolites produced by Colletotrichum sp., an endophytic fungus in Artemisia annua. Plant Science 151, 67-73.

Maharachchikumbura SSN, Hyde KD, Jones EBG, McKenzie EHC, Huang S-K, AbdelWahab MA, Daranagama DA, Dayarathne M, D'souza M, Goonadekara ID, 
Hongsanan S, Jayawardena RS, Kirk P, Konta S, Liu J-K, Norphanphoun C, Pang KL, Perera RH, Senanayake IC, Shang Q, Shenoy D, Xiao Y, Xu J. 2015 - Towards a natural classification and backbone tree for Sordariomycetes. Fungal Diversity 72, 199-301.

Maharachchikumbura SN, Hyde KD, Jones EBG, McKenzie EHC, Bhat JD, Dayarathne MC, Huang SK, Norphanphoun C, Senanayake IC, Perera RH, Shang QJ, Xiao Y, D'souza MJ, Hongsanan S, Jayawardena RS, Daranagama DA, Konta S, Goonasekara ID, Zhuang WY, Jeewon R, Phillips AJL, Abdel-Wahab MA, Al-Sadi AM, Bahkali Ah, Boonmee S, Boonyuen N, Cheewangkoon R, Dissanayake AJ, Kang J, Li QR, Liu JK, Liu XZ, Liu ZY, Luangsa-ard JJ, Pang KL, Phookamsak R, Promputtha I, Suetrong S, Stadler M, Wen T, Wijayawardene NN. 2016 - Families of Sordariomycetes. Fungal Diversity $79,1-317$.

Manamgoda DS, Udayanga D, Cai L, Chukeatirote E, Hyde KD. 2013 - Endophytic Colletotrichum from tropical grasses with a new species $C$. endophytica. Fungal Diversity 61, 107-115.

Marcelino J, Giordano R, Gouli S, Gouli V, Parker BL, Skinner M, TeBeest D, Cesnik R. 2008 - Colletotrichum acutatum var. foriniae (teleomorph: Glomerella acutata var. foriniae var. nov. infection of a scale insect. Mycologia 100, 353-374.

Marcelino JAP, Gouli S, Parker BL, Skinner M, Schwarzberg L, Giordano R. 2009 - Host plant associations of an entomopathogenic variety of the fungus, Colletotrichum acutatum, recovered from the elongate hemlock scale, Fiorinia externa. Journal of Insect Science 9, 25.

Mejía LC, Rojas EI, Maynard Z, Van Bael S, Arnold AE, Hebber P, Samuels GJ, Robbins N, Herre EA. 2008 - Endophytic fungi as biocontrol agents of Theobroma cacao pathogens Biological Control 46, 4-14.

Miyazawa M, Okamura S, Yamaguchi M, Kameoka H. 2000 - Biological stereoselective reduction of 4-methylcyclohexanone and 4-ethylcyclohexanone by anthracnose fungi. The Journal of Chemical Technology and Biotechnology 75, 143-146.

Mousa WK, Raizada MN. 2013 - The diversity of anti-microbial secondary metabolites produced by fungal endophytes: an interdisciplinary perspective. Frontiers in Microbiology 4, article 65.

O'Connell RJ, Thon MR, Hacquard S, Amyotte SG, Kleemann J, Torres MF, Damm U, Buiate EA, Epstein L, Alkan N, Altmüller, Alvarado-Balderrama L, Bauser CA, Becker C, Birren BW, Chen Z, Choi J, Crouch JA, Duvick JP, Farman MA, Gan P, Heiman D, Henrissat B, Howard RJ, Kabbage M, Koch C, Kracher B, Kubo Y, Law AD, Lebrun MH, Lee YH, Miyara I, Moore N, Neumann U, Nordström, Panaccione DG, Panstruga R, Place M, Proctor RH, Prusky D, rech G, Reinhardt R, Rollins JA, Rounsley S, Schardl CL, Schwartz DC, Shenoy N, Shirasu K, Sikhakolli UR, Stüber K, Sukno SA, Sweigard JA, Takano Y, Takahara H, Trail F, Zhou S, Dickman MB, Schulze-Lefert P, Loren van Themaat EV, Ma LJ, Vaillancourt LJ. 2012 - Life-style transitions in plant pathogenic Colletotrichum fungi deciphered by genome and transcriptome analyses. Nature Genetics 44, 1060-1065.

Ohra J, Morita K, Tsujino Y, Tazaki H, Fujimori Y, Goering M, Zoner P. 1995 - Production of the phytotoxic metabolite, ferricrocin, by the fungus Colletotrichum gloeosporioides. Bioscience, Biotechnology and Biochemistry 59, article 113.

Pusztahelyi T, Holb IJ, Pócsi I. 2015 - Secondary metabolites in fungus-plant interactions. Frontiers in Plant Science 6, article 573.

Ren Y, Strobel GA, Graff JC, Jutila M, Park SG, Gosh S, Teplow D, Condron M, Pang E, Hess WM, Moore E. 2008 - Colutellin A, an immunosuppressive peptide from Colletotrichum dematium. Microbiology 154, 1973-1979. 
Rojas EI, Rehner SA, Samuels GJ, Van Bael SA, Herre EA, Cannon P, Chen R, Pang J, Wang R, Zhang Y, Peng YQ. 2010 - Colletotrichum gloeosporioides s. 1. associated with Theobroma cacao and other plants in Panama: multilocus phylogenies distinguish pathogen and endophyte clades. Mycologia 102, 1318-1338.

Senthilkumar N, Murugesan S, Mohan V, Muthumary J. 2013 - Taxol producing fungal endophyte, Colletotrichum gloeosporioides (Penz.) from Tectona grandis L. Current Biotica 7, 8-15.

Singh J, Quereshi S, Banerjee N, Pandey AK. 2010 - Production and extraction of phytotoxins from Colletotrichum dematium FGCC\#20 effective against Parthenium hysterophorus L. Brazillian Archives of Biology and Technology 53, 669-678.

Somashekhara Achar KG, Shivanna MB. 2013 - Foliar disease of Clitorea ternatea due to Colletotrichum dematium and its effect on secondary metabolite production. Archives of Phytopathology and Plant Protection 46, 990-1004.

Templeton GE. 1974 - Endemic fungus disease for control of prickly sida in cotton and soybeans. Arkansas Farm Res 23, article 12.

Templeton GE. 1991 - Use of Colletotrichum strains as mycoherbicides. In: Colletotrichum: Biology, pathology and control (Bailey JA and Jeger MJ Eds.). CAB International, Wallingford, UK 358-380.

Templeton MD, Rikkerink EHA, Solon SL, Crowhurst RN. 1992 - Cloning and molecular characterization of the glyceraldehyde-3-phosphate dehydrogenaseencoding gene and cDNA from the plant pathogenic fungus Glomerella cingulata. Gene 122, 225230 .

Trujillo EE, Latterell FM, Rossi AE. 1986 - Colletotrichum gloeosporioides, a possible biological control agent for Clidemia hirta in Hawaiian forests. Plant Disease 70, 974-976.

Tunali B, Berner DK, Dubin HJ. 2008 - First report of leaf spot caused by Colletotrichum cf. linicola on field bindweed in Turkey. Plant Disease 92, 316.

Tunali B, Kansu B, Berner DK. 2009 - Biological control studies on Convolvulus arvensis L. with fungal pathogens. Journal of Turkish Phytopathology 38, 1-8.

Velasco R, Gil JH, García CM, Durango DL. 2010 - Production of 2-phenylethanol in the biotransformation of cinnamyl alcohol by the plant pathogenic fungus Colletotrichum acutatum. Vitae 17, 272-280.

Velasco-Bucheli R, Mesa A, Gil J, García C, Durango D. 2015 - Transformation of transAnethole using the plant pathogenic fungus Colletotrichum acutatum as biocatalyst. Revisra Mexicana de Ingeniería Química 14, 653-666.

Weber N, Schmitzer V, Jakopic J, Mikulic-Petkovsek M, Stamper F, Koron D, Veberic R. 2013 - Influence of Colletotrichum simmondsii R. G. Shivas \& Y. P. Tan infection on selected primary and secondary metabolites in strawberry (Fragaria $\times$ ananassa Duch.) fruit and runners. European Journal of Plant Pathology 136, 281-290.

Weir BS, Johnston PR, Damm U. 2012 - The Colletotrichum gloeosporioides species complex. Studies in Mycology 73, 115-180.

Wicklow DT, Jordan AM, Gloer JB. 2009 - Antifungal metabolites (monorden, monocillins I, II, III) from Colletotrichum graminicola, a systemic vascular pathogen of maize. Mycological Research 113, 1433-42.

Wilson MR, Gallimore WA, Reese PB. 1999 - Steroid transformations with Fusarium oxysporum var. cubense and Colletotrichum musae. Steroids 64, 834-843.

Wu Y, Li H, Zhang XM, Gong JS, Rao ZM, Shi JS, Zhang XJ, Xu ZH. 2015 - Efficient hydroxylation of functionalized steroids by Colletotrichum lini ST-1. Journal of Molecular Catalysis B: Enzymatic 120, 111-118. 
Wymore LA, Poirier C, Watson AK, Gotlieb Ar. 1988 - Colletotrichum coccodes, a potential bioherbicide for control of velvetleaf (Abutilon theophrasti). Plant Disease 72, 534538.

Xiong ZQ, Yang YY, Zhao N, Wang Y. 2013 - Diversity of endophytic fungi and screening of fungal paclitaxel producer from Anglojap yew, Taxus $\times$ media. BMC Microbiology 13, article 1.

Xu D, Tsai CJ, Nussinov R. 1997 - Hydrogen bonds and salt bridges across protein-protein interfaces. Protein Engineering, Design and Selection 10, 999-1012.

Yang YK, Kim SO, Chung HS, Lee YH. 2000 - Use of Colletotrichum graminicola KA001 to control barnyard grass. Plant Disease 84, 55-59.

Yogeeswari P, Sriram D. 2005 - Betulinic acid and its derivatives: a review on their biological properties. Current Medicinal Chemistry 12, 657-666.

Zhang G, Wang W, Zhang X, Xia Q, Zhao X, Ahn Y, Ahmed N, Cosoveanu A, Wang M, Wang J, Shu S. 2015 - De Novo RNA sequencing and transcriptome analysis of Colletotrichum gloeosporioides ES026 reveal genes related to biosynthesis of huperzine A. PLoS One 23, article e0120809.

Zhang TY. 1985 - A forma specialis of Colletotrichum gloeosporioides on Cuscuta sp. Acta Mycologica Sinica 4, 223-239. [In Chinese]

Zou WX, Meng JC, Lu H, Chen GX, Shi GX, Zhang TY, Tan RX. 2000 - Metabolites of Colletotrichum gloeosporioides, an endophytic fungus in Artemisia mongolica. Journal of Natural Products 63, 1529-1530. 